\title{
Evaluating the Safety of Sodium Hypochlorite Usage as an Irrigation Solution in Acute Osteomyelitis: an Experimental Study in Rat Tibia via a Renewed Osteomyelitis Model
}

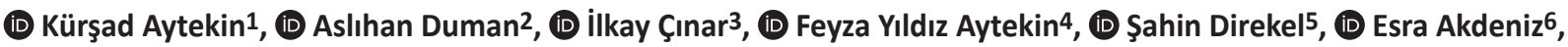 \\ (D) Selçuk Takır7, (1D Cem Zeki Esenyel8
}

1 Giresun University Faculty of Medicine, Department of Orthopaedic and Traumatology, Department of Anatomy, Giresun, Turkey 2Giresun University Faculty of Medicine, Department of Pathology, Giresun, Turkey

3 Giresun University Faculty of Medicine, Department of Pathology, Giresun, Turkey

${ }^{4}$ Ministery of Health, Giresun University Prof. Dr. A. IIhan Özdemir Training and Research Hospital, Department of Infectious Diseases and Clinical Microbiology, Giresun, Turkey

5 Giresun University Faculty of Medicine, Department of Microbiology, Giresun, Turkey

6 Marmara University Faculty of Medicine, Department of Biostatistics, Istanbul, Turkey

7 Giresun University Faculty of Medicine, Department of Pharmacology, Giresun, Turkey

8 Giresun University Faculty of Medicine, Department of Orthopaedic and Traumatology, Giresun, Turkey

\section{Abstract}

Objective: The ideal irrigation solution for osteomyelitis surgery has not yet been clarified. The aim of this study is to evaluate the therapeutic effect and the optimum concentration of sodium hypochlorite ( $\mathrm{NaOCl}$ ) solution for the mechanical treatment of acute osteomyelitis.

Methods: Fourty tibias of 20 male Wistar rats were used. The medullas were percutaneously inoculated with Staphylococcus aureus ATCC 25923 to induce acute osteomyelitis in tibias. One week later, rats were randomly assigned to 3 treatment groups and irrigated with $0.5 \%$, $1 \%$ and $5 \% \mathrm{NaOCl}$. Irrigation with saline was used at positive control group and any treatment was not given to negative control group. All rats were sacrificed 24 hours after $\mathrm{NaOCl}$ irrigation. The degree of bacterial density, necrosis, inflammation and edema were evaluated histologically as; none (0), mild (1), moderate (2) and severe (3). Kruskal-Wallis and Dunn tests were used for statistical evaluations.

Results: Acute osteomyelitis developed in all tibias. $\mathrm{NaOCl}$ treatment no matter the concentration reduced the bacterial density compared to negative control group. The decrease in bacterial density and inflammation was significant at $0.5 \% \mathrm{NaOCl}$ group compared to positive group (respectively; $p=0.019, p=0.045$ ), while the pairwise comparisons were statistically insignificant in terms of necrosis and edema. There was not any statistically difference between positive and 1\%-5\% NaOCl groups in terms of bacterial density.

Conclusion: In conclusion, irrigation with $0.5 \% \mathrm{NaOCl}$ was more therapeutic than saline, $1 \% \mathrm{NaOCl}$ and $5 \% \mathrm{NaOCl}$ concentrations for acute tibia osteomyelitis at rats while $0.5 \% \mathrm{NaOCl}$ group was same with saline group in terms of safety to tissue.

Keywords: Acute osteomyelitis model, experimental animal model, rat, sodium hypochlorite irrigation, treatment

\section{INTRODUCTION}

Acute osteomyelitis, a disease of bone due to the infection, rare but serious condition, is great concern in orthopedic surgeries. The most cause of the acute osteomyelitis is the hematogenous spread of the causative bacteria into the bone, and less cause by surgery as open fracture surgery, or bone surgery including joint replacements/osteosynthesis (1). It develops rapidly over a period of 7 to 10 days, and in some specific situations (i.e. presence of heart failure, immunosuppressant medications) can 
be life treating $(1,2)$. In the treatment, debridement and irrigation with several solutions during the surgery, and antibiotic usage are the first line options with the aim to control and remove the infection (2). The people infected might need to get their antibiotic medications for several weeks and in more serious osteomyelitis, surgery to remove the infected tissue and bone might be required.

The irrigation with solutions is commonly performed in orthopedic surgeries to keep patient from risk of infection. Isotonic saline, disinfectants or antibiotic solutions may be used as irrigation solution (3-6). In most circumstances saline is preferred for the irrigation of surgical site but it does not have any effect on microorganisms (4). The usage of antibiotic solutions is very limited because of its higher cost and antibiotic resistance but disinfectants remain as an option (4). The appropriate solution for irrigation has not been clarified thus far (2). Owing to rising antibiotic resistance in recent years, the importance of irrigation solutions has increased further (1). This, in turn, has revealed the importance of the antimicrobial effects of irrigation solutions (2).

To perform a most proper treatment for acute osteomyelitis, animal studies are done by using foreign body (7). Because the difficulty of performing infection at rats, the majority of osteomyelitis performing models use foreign objects as sclerosing material, heat or necrosis (7-9). The common source for acute osteomyelitis is known to be Staphylococcus aureus due to hematogenous transmission $(1,2)$. Due to the usage of foreign objects as sclerosing material, heat or necrosis at osteomyelitis models, we think these performed techniques don't reflect exactly the acute osteomyelitis.

Sodium hypochlorite $(\mathrm{NaOCl})$ is common used disinfectant in general purpose and health care services. It has lethal effect on viruses, fungi and wide spread of bacteria, and hence it is used for tap water disinfection (10). $\mathrm{NaOCl}$ is reported to be toxic to cell even at very lower concentration (0.01\%) in vitro (11). Though the in vitro studies, in management of dental infections, $0.5 \%$ to $5 \% \mathrm{NaOCl}$ solutions are used for irrigation with success (12-14). However, $\mathrm{NaOCl}$ solutions are not routinely used as an irrigation solution for osteomyelitis surgeries.

In the present study, we aimed to investigate the safety and the efficacy of different concentrations ( 0.5 to $5 \%$ ) of $\mathrm{NaOCl}$ due to a renewed acute osteomyelitis model of rat tibia.

\section{METHODS}

The study was conducted upon the permission of local ethics committee for animal experiments (HADYEK, 15.12.2016,
2016/16). Twenty male Wistar albino rats weighing 200-250 g were used. All animals involved in experiments have received humane care in compliance with the Guide for the Care and Use of Laboratory Animals (15). Rats were fed ad libitum; the temperature was $22+/-2^{\circ} \mathrm{C}$ with the $50 \%$ humidity. The rats were kept at $12 / 12 \mathrm{~h}$ dark and light cycles. To prevent unnecessary animal sacrificing, both tibias of all animals were used.

\section{Fluids Used for Irrigation and Creating the Groups}

At the surgical processes under anesthesia, 2 rats were died. The remaining 18 rats were randomly divided into 5 groups. The $1^{\text {st }}$ group was the negative control group (group 1) ( $n=3$ rats, $n=6$ tibias) for which no treatment was applied. The $2^{\text {nd }}$ group was the positive control group (group 2 ) ( $n=3$ rats, $n=6$ tibias) which was treated with saline ( $0.9 \% \mathrm{NaCl}$ isotonic) as it is routinely used in surgery. The other three groups were treatment groups and were named as; $0.5 \% \mathrm{NaOCl}$ (group 3) ( $\mathrm{n}=4$ rats, $\mathrm{n}=8$ tibias), $1 \%$ $\mathrm{NaOCl}$ (group 4) ( $\mathrm{n}=4$ rats, $\mathrm{n}=8$ tibias) and $5 \% \mathrm{NaOCl}$ (group 5) $(\mathrm{n}=4$ rats, $\mathrm{n}=8$ tibias). A brief summary of groups and applied treatments are given at Table 1.

\section{Preparation of Bacterial Suspensions}

Standard Methicillin-sensitive Staphylococcus aureus (MSSA) ATCC 25923 isolate, stored in freezer at $-80^{\circ} \mathrm{C}$ was brought to room temperature and then incubated overnight in 5\% sheep's blood agar passaging at $37^{\circ} \mathrm{C}$. The next day after purity check of bacteria, bacterial suspensions with McFarland 10 turbidity (approximately $3 \times 10^{9} \mathrm{cfu} / \mathrm{mL}$ ) were prepared in saline.

\section{Induction of Osteomyelitis and Irrigation}

All rats had intraperitoneal ketamine $(50 \mathrm{mg} / \mathrm{kg}$ ) (Ketalar; Eczacıbaşı, İstanbul, Turkey) and xylazine $(10 \mathrm{mg} / \mathrm{kg}$ ) (Rompun; Bayer, Leverkusen, Germany) for anesthesia. Knees were wiped with povidone iodine. Supplemental analgesia was provided by intraperitoneal injection of buprenorphine $(0.3 \mathrm{mg} / \mathrm{kg})$. The

\begin{tabular}{|l|l|l|l|}
\hline \multicolumn{4}{|c|}{ Table 1. Tibia numbers in groups, treatments applied to rats } \\
\hline $\begin{array}{l}\text { Group } \\
\text { number }\end{array}$ & $\begin{array}{l}\text { Group } \\
\text { name }\end{array}$ & $\begin{array}{l}\text { Number of } \\
\text { tibias (n) }\end{array}$ & Treatment administered \\
\hline 1 & $\begin{array}{l}\text { Negative } \\
\text { control }\end{array}$ & 6 & No treatment \\
\hline 2 & $\begin{array}{l}\text { Positive } \\
\text { control }\end{array}$ & 6 & $\begin{array}{l}\text { Irrigation with } 20 \mathrm{~mL} \text { of } \\
\text { saline }\end{array}$ \\
\hline 3 & $0.5 \% \mathrm{NaOCl}$ & 8 & $\begin{array}{l}\text { Irrigation with } 20 \mathrm{~mL} \text { of } \\
0.5 \% \text { NaOCl }\end{array}$ \\
\hline 4 & $1 \% \mathrm{NaOCl}$ & 6 & $\begin{array}{l}\text { Irrigation with } 20 \mathrm{~mL} \text { of } 1 \% \\
\text { NaOCl }\end{array}$ \\
\hline 5 & $5 \% \mathrm{NaOCl}$ & 8 & $\begin{array}{l}\text { Irrigation with } 20 \mathrm{~mL} \text { of } 5 \% \\
\text { NaOCl }\end{array}$ \\
\hline \multicolumn{2}{|l}{$\mathrm{NaOCl:} \mathrm{Sodium} \mathrm{hypochlorite}$} &
\end{tabular}


tuberositas tibia (TT) was palpated. Percutaneous drilling with a 22-gauge needle tip (without skin incision) from the TT to tibial medulla was performed (16). After drilling, a 26-gauge needle tip was used to inoculate the medulla percutaneously with $10 \mu \mathrm{L}$ (nearly $3 \times 10^{7} \mathrm{cfu}$ ) of the bacterial suspension of Staphylococcus aureus. During follow-up, $7.5 \mathrm{mg} / \mathrm{kg}$ paracetamol (Parol, Atabay, İstanbul, Turkey) was added to drinking water.

After 7 day of inoculation with bacterial suspension to the rat tibias, experimentations in all groups were performed under ketamine $(50 \mathrm{mg} / \mathrm{kg}) / x y l a z i n e ~(10 \mathrm{mg} / \mathrm{kg})$ anesthesia with buprenorphine $(0.3 \mathrm{mg} / \mathrm{kg})$ analgesia. After the knee joints were wiped with povidone iodine, $1 \mathrm{~cm}$ longitudinal incision was done to the TT. Using the previous entry point, the tibia medulla was manually drilled with 22-gauge needle tip. At the point where the needle entered the bone, soft tissues were excised to allow fluid flow out of the medulla. Then the tibias in the groups were irrigated with the relevant solutions for 30 seconds. After the irrigation, 4/0 no absorbable polypropylene sutures (Propilen; Doğsan Tıbbi Malzeme San A.Ş, Trabzon, Turkey) were used to close the skin. At follow-up, rats received $7.5 \mathrm{mg} / \mathrm{kg}$ paracetamol ad libitum in drinking water. After irrigation, 1 rat in the $1 \%$ $\mathrm{NaOCl}$ group died (3 rats died in sum).

\section{Radiological Magnetic Resonance Imaging (MRI) Assessment of Osteomyelitis Induction}

On the $7^{\text {th }}$ day of the study, rats were anesthetized intraperitoneally with ketamine $(50 \mathrm{mg} / \mathrm{kg}$ ) and xylazine $(10 \mathrm{mg} / \mathrm{kg})$.

To determine whether osteomyelitis developed in rats with tibias inoculated with bacteria or not, contrast $(0.1 \mathrm{mmol}$ gadobutrol/kg) T1 MRI (Siemens Magnetom Aera 1.5T, Erlangen, Germany) was used (17). Contrast material was administered intraperitoneally. Thin sagittal sections of the tibia were taken (Figure 1). As tibias without contrast would not be included in the study, a radiologist, and an orthopedist assessed results during imaging.

\section{Histopathology}

On the $8^{\text {th }}$ day of the study (24 hours after irrigation), the rats were sacrificed with high doses of ketamine $(100 \mathrm{mg} / \mathrm{kg}$ ) and xylazine $(100 \mathrm{mg} / \mathrm{kg})$ anesthesia. Both tibias of rats (total 34) were dissected, including the soft tissues surrounding the tibias, and placed into 10\% formalin, and submerged in paraffin. Sagittal sections in $4 \mu \mathrm{m}$ thickness were taken with a microtome (Thermo Scientific Microm HM 340E). Paired consecutive sections from each tibia were stained with $\mathrm{HE}$ and two were stained with Giemsa. Two different pathologist under a light microscope (Olympus CX41) performed histopathological assessments in blind. Bone and soft tissues were assessed for necrosis, inflammation, edema and bacterial density. For all assessments, scoring was none (0), mild (1), moderate (2) and severe (3) according to density and spread of the parameter examined (18).

\section{In Vitro Investigation of Antibacterial Activity of NaOCL Against Standard Pathogenic Bacterias}

An in vitro study was conducted to investigate the effectiveness of the $\mathrm{NaOCl}$ available. The aim of this investigation was to evaluate the antibacterial activity of $\mathrm{NaOCl}$ against four different standard bacteria with minimal inhibitor concentrations by alamar blue microdilution broth method. The standard obtained from the American type culture collection (ATCC); MSSA ATCC 25923, Escherichia coli ATCC 25922, Salmonella typhimurium ATCC 14028, Pseudomonas aeruginosa ATCC 27853 isolates were used. Serial dilution of $\mathrm{NaOCl}$ was carried out in sterile microplates of 96 wells, ranging from $1 / 2$ to $1 / 1024$ in Mueller Hinton Broth (MHB, Merck) medium. Suspensions of standard bacteria (turbidity number 107-108 cfu/mL) adjusted to McFarland 0.5 turbidity were added $100 \mathrm{~mL}$ to wells and incubated at $37^{\circ} \mathrm{C}$. The last two wells were used as a negative (only medium and $\mathrm{NaOCl}$ ) and positive (only medium and bacteria) control. After 20 hours, $20 \mu \mathrm{L}$ of alamar blue (SigmaAldrich, USA) was added to the microplates and incubated for another 4 hours. The change of the alamar blue in the wells to pink color according to the color change was interpreted as the presence of reproduction or the absence of color change was interpreted as stopping the reproduction. In addition, samples were taken from the wells were cultivated and reproduction was

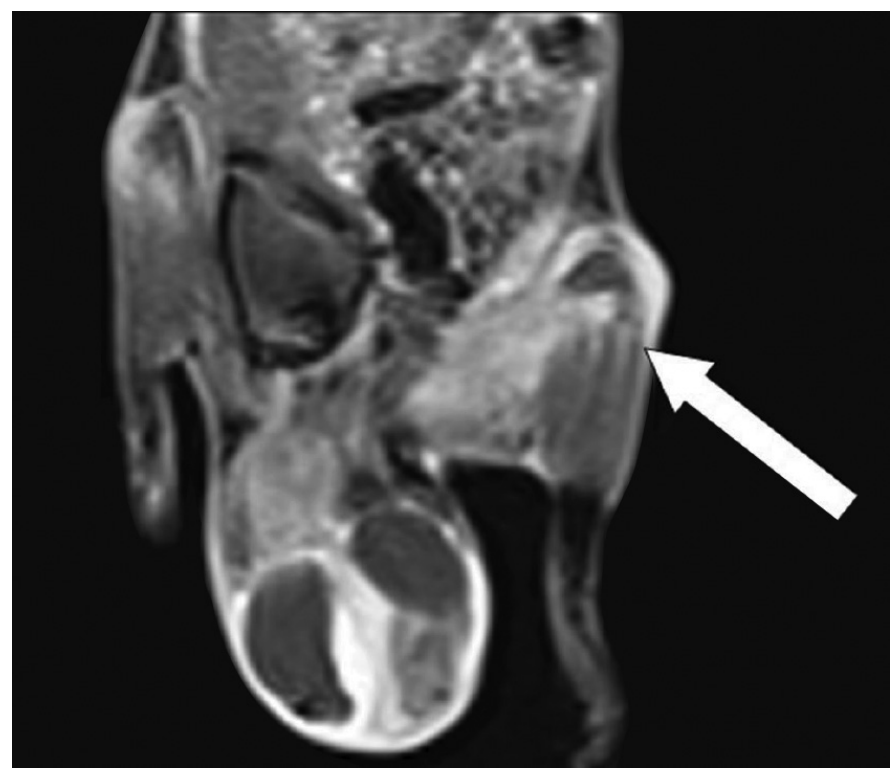

Figure 1. Contrast T1 MRI showing significant contrast enhancement MRI: Magnetic Resonance Imaging 
checked. The concentration of stock $\mathrm{NaOCl}$ used was $5 \%$. The concentrations were reduced by half and half.

\section{Statistical Analysis}

Statistical analyses were performed using R 3.5.1 Statistical Software (r-project), a free software environment for statistical computing and graphics. ICC estimates and their $95 \%$ confidence intervals were calculated using SPSS statistical package version 17.0 (SPSS Inc, Chicago, IL) based on a mean-rating $(k=2)$, consistency and 2-way random-effects model. ICC values less than 0.5 , between 0.5 and 0.75 , between 0.75 and 0.9 , and greater than 0.90 were indicative of poor, moderate, good, and excellent reliability, respectively (19).

The variables in the study were measured at an ordinal level thus the baseline characteristics of the groups were presented as median and interquartile range. The Kruskal-Wallis test was used as an omnibus test to compare medians of groups (20). Dunn multiple comparison test (21) was used after significant Kruskal-Wallis test (20). DunnTest function in FAS package of the $\mathrm{R}$ program was used for multiple comparisons. P values adjusted with the False Discovery Rate method were given.

\section{RESULTS}

Comparing the two observers to one another, the intra class correlation for edema, inflammation and necrosis were 0.90 (95\% confidence interval (Cl): 0.77-0.912), 0.914 (95\% Cl: 0.754$0.981)$ and 0.843 (95\% Cl: 0.617-0.940), respectively.

It was of interest to test whether there was a significant difference among negative control, positive control, $0.5 \% \mathrm{NaOCl}, 1 \% \mathrm{NaOCl}$, and $5 \% \mathrm{NaOCl}$ groups in terms of necrosis, inflammation in soft tissues and bones, edema in soft tissues, and bacterial density in bones. Descriptive statistics of variables for each group and the associated $p$ values of the Kruskal-Wallis tests are shown in Table 2. Significant differences were found between the groups in terms of inflammation in soft tissues, necrosis, inflammation and bacterial density in bones with $p$ values of $0.0241,0.0239$,
0.00022 and $<0.001$, respectively (Table 2 ). The adjusted $p$ values of post hoc tests are shown in Table 3.

\section{Percutaneous Staphylococcus Aureus Inoculation to Rat Tibias Caused Acute Osteomyelitis}

With the percutaneous bacteria inoculation method, we identified the success rate for acute tibial osteomyelitis to be $100 \%$ in rat tibias. Investigated with contrast T1 MRI, 34 tibias of 17 rats were identified to have acute osteomyelitis. Contrast material involvement was observed in all of the 34 tibia medullas and in soft tissues surrounding tibias (Figure 1). After sacrificing; necrosis, acute inflammation and edema in surrounding soft tissues, bone marrows and soft tissues in all tibias with $\mathrm{HE}$ staining, and bacterial colonization with Giemsa staining were observed in histopathological investigations.

\section{Irrigation with $\mathrm{NaOCI}$ Reduced Bacterial Density}

While the density of bacteria was assessed histopathologically with Giemsa staining, a variety of dimensions and densities of bacterial colonization were observed and classified (Figure 2). Significant differences were found between groups in terms of bacterial density in bones. No significant differences were found between negative and positive control groups in pairwise comparisons ( $p=0.388$ ) (Table 3). The $0.5 \% \mathrm{NaOCl}, 1 \% \mathrm{NaOCl}$ and $5 \% \mathrm{NaOCl}$ groups had significantly lower amount of bacterial density in bones than that of the negative control group (negative control vs. $0.5 \% \mathrm{NaOCl}, \mathrm{p}<0.001$; negative control vs $1 \% \mathrm{NaOCl}, \mathrm{p}=0.039$; negative control vs $5 \% \mathrm{NaOCl}, \mathrm{p}<0.001)$. The $0.5 \% \mathrm{NaOCl}$ group had a significantly lower amount of bacterial density in bones than that of the positive control group (Table 3) (positive control vs $0.5 \% \mathrm{NaOCl}, \mathrm{p}=0.019$ ). The $1 \% \mathrm{NaOCl}$ and $5 \% \mathrm{NaOCl}$ groups had no significant difference compared to the positive control group (Table 3) (positive control vs $1 \% \mathrm{NaOCl}$, $p=0.192$; positive control vs $1 \% \mathrm{NaOCl}, \mathrm{p}=0.186$ ).

These findings show that $\mathrm{NaOCl}$ usage reduced the density of bacteria. With $0.5 \% \mathrm{NaOCl}$ usage, bacterial density was significantly reduced compared to the positive control group.

Table 2. Descriptive statistics and Kruskal-Wallis test results

\begin{tabular}{|l|l|l|l|l|l|l|l|}
\hline \multicolumn{2}{|c|}{} & Negative control & Positive control & $\mathbf{0 . 5 \% ~ N a O C l}$ & $\mathbf{1 \% ~ N a O C l}$ & $\mathbf{5 \% ~ N a O C l}$ & Test statistic (p) \\
\hline \multirow{5}{*}{ Bone marrows } & Bacterial density & $3(0)$ & $2(0.75)$ & $1(0.25)$ & $2(0.75)$ & $1(0)$ & $25.7\left(<0.001^{*}\right)$ \\
\cline { 2 - 8 } & Necrosis & $2(0)$ & $1(0.75)$ & $1(0.25)$ & $1.5(1)$ & $2(0)$ & $12.95\left(0.02^{*}\right)$ \\
\cline { 2 - 8 } & Inflammation & $3(0)$ & $2.5(1)$ & $2(0)$ & $2(0)$ & $2(0)$ & $18.66\left(0.002^{*}\right)$ \\
\hline \multirow{5}{*}{ Soft tissues } & Necrosis & $1(0.75)$ & $1(0.75)$ & $0(0.25)$ & $0.5(1)$ & $1(1.25)$ & $4.49(0.48)$ \\
\cline { 2 - 7 } & Edema & $2(0)$ & $2(0)$ & $2(1)$ & $2(0)$ & $2(0.25)$ & $7.06(0.21)$ \\
\cline { 2 - 7 } & Inflammation & $3(0.75)$ & $3(0)$ & $2(0.5)$ & $2(0.75)$ & $12.9\left(0.02^{*}\right)$ \\
\hline
\end{tabular}




\section{Irrigation with $\mathrm{NaOCI}$ Reduced Inflammation}

Inflammation was assessed with HE staining. During assessment of inflammation, neutrophil density in bone marrows was observed to decrease (Figure 3). No significant difference was found in bone marrows between negative and positive control groups in terms of inflammation ( $p=0.383$ ) (Table 3). The $0.5 \%$ $\mathrm{NaOCl}, 1 \% \mathrm{NaOCl}$ and $5 \% \mathrm{NaOCl}$ groups had significantly lower amounts of inflammation in bone marrows than that of the

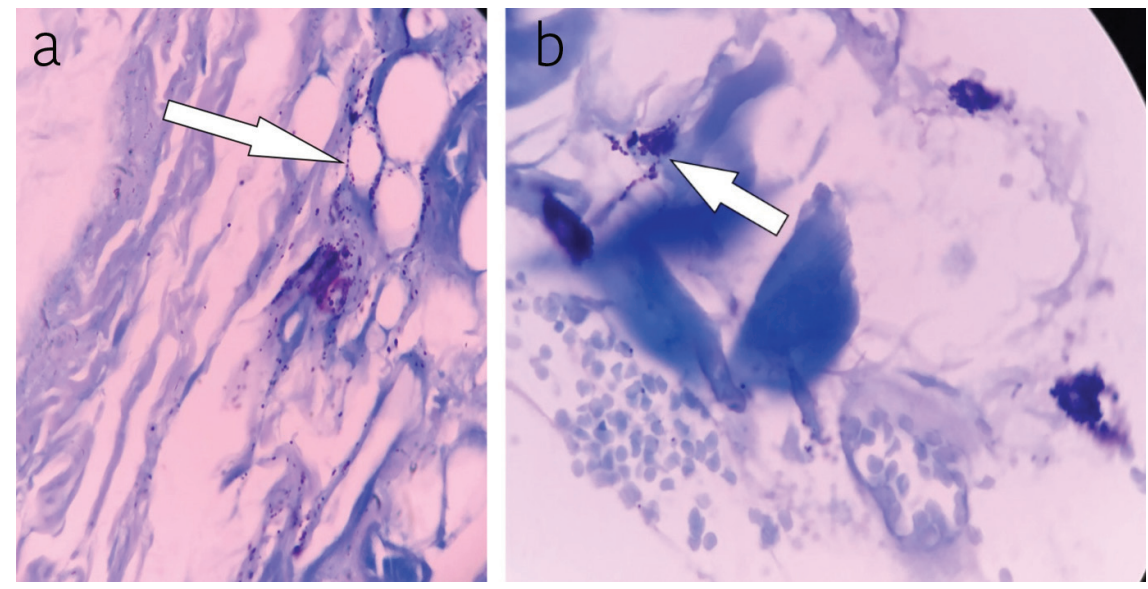

Figure 2. Bacterial density (Giemsa staining, 40x100 magnification). Arrows indicate the bacteria; a) 0.5\% NaOCl group, score 1, b) positive control group, score 3

$\mathrm{NaOCl}$ : Sodium hypochlorite
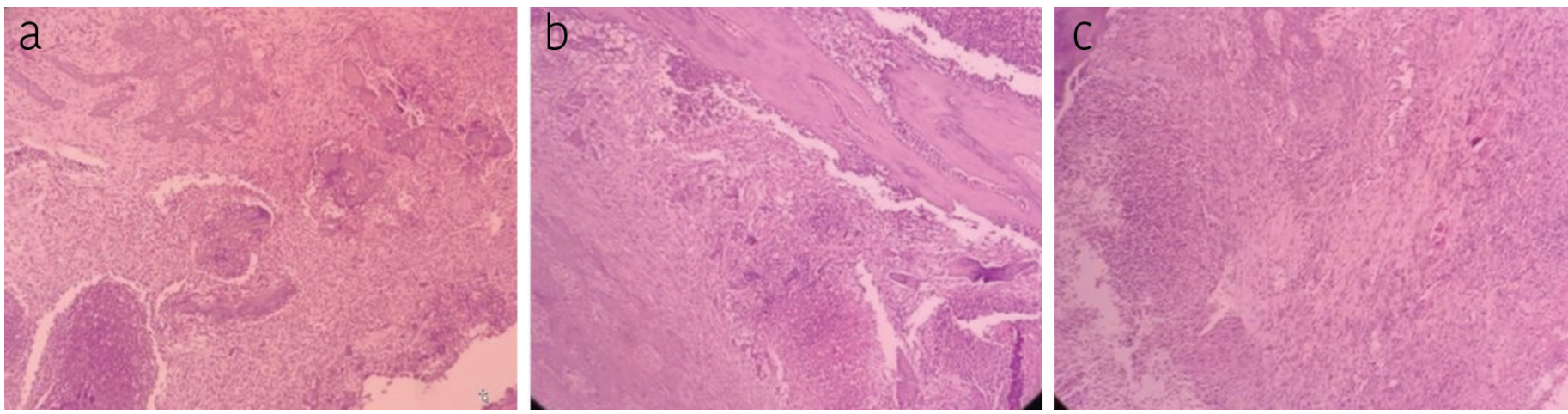

Figure 3. Inflammation and necrosis of soft tissues and bones ( $\mathrm{H} \& \mathrm{E} 10 \times 100)$; a) $0.5 \% \mathrm{NaOCl}$ (irrigation with $0.5 \% \mathrm{NaOCl}$ ), necrosis score 1 , inflammation score 3, b) positive control (irrigation with saline, necrosis score 1, inflammation score 2, c) negative control (no irrigation) necrosis score 1, inflammation score 3

$\mathrm{NaOCl}$ : Sodium hypochlorite, $\mathrm{H} \& \mathrm{E}$ : Haematoxylin and eosin

\begin{tabular}{|l|l|l|l|l|}
\hline Table 3. Multiple comparisons for significant tests (adjusted $\mathbf{p}$ values) \\
\hline Comparison & $\begin{array}{l}\text { Bacterial density in } \\
\text { bones }\end{array}$ & $\begin{array}{l}\text { Necrosis in bone } \\
\text { marrows }\end{array}$ & $\begin{array}{l}\text { Inflammation in bone } \\
\text { marrows }\end{array}$ & $\begin{array}{l}\text { Inflammation in soft } \\
\text { tissues }\end{array}$ \\
\hline Negative control - positive control & 0.388 & 0.108 & 0.383 & 0.575 \\
\hline Negative control - 0.5\% NaOCl & $<0.001$ & 0.086 & 0.011 & 0.182 \\
\hline Negative control - $\% \mathrm{NaOCl}$ & 0.039 & 0.334 & 0.045 & 0.511 \\
\hline Negative control - 5\% NaOCl & $<0.001$ & 0.891 & 0.036 & 0.189 \\
\hline Positive control - 0.5\% NaOCl & 0.019 & 0.964 & 0.094 & 0.045 \\
\hline Positive control - 1\% NaOCl & 0.192 & 0.555 & 0.285 & 0.153 \\
\hline Positive control - 5\% NaOCl & 0.186 & 0.081 & 0.325 & 0.031 \\
\hline $0.5 \% \mathrm{NaOCl}-1 \% \mathrm{NaOCl}$ & 0.326 & 0.528 & 0.727 & 0.650 \\
\hline $0.5 \% \mathrm{NaOCl}-5 \% \mathrm{NaOCl}$ & 0.703 & 0.076 & 0.914 \\
\hline $1 \% \mathrm{NaOCl}-5 \% \mathrm{NaOCl}$ & 0.209 & 0.252 & 0.872 & 0.674 \\
\hline NaOCl: Sodium hypochlorite & & & \\
\hline
\end{tabular}


negative control group (negative control vs $0.5 \% \mathrm{NaOCl}, \mathrm{p}=0.011$; negative control vs $1 \% \mathrm{NaOCl}, p=0.045$; negative control vs $5 \%$ $\mathrm{NaOCl}, p=0.036$ ) (Table 3). No significant difference was found in terms of inflammation in bone marrows between the positive control group and $0.5 \% \mathrm{NaOCl}, 1 \% \mathrm{NaOCl}$ and $5 \% \mathrm{NaOCl}$ groups (positive control vs $0.5 \% \mathrm{NaOCl}, \mathrm{p}=0.094$; positive control vs $1 \%$ $\mathrm{NaOCl}, \mathrm{p}=0.285$; positive control vs $5 \% \mathrm{NaOCl}, \mathrm{p}=0.325$ ) (Table 3).

In assessment of inflammation, neutrophil density in soft tissues was observed to decrease. No significant difference was found in soft tissues between negative and positive control groups in terms of inflammation $(p=0.575)$ (Table 3$)$. Also no significant difference was found in soft tissues in terms of inflammation between negative and $0.5 \% \mathrm{NaOCl}, 1 \% \mathrm{NaOCl}$, and $5 \% \mathrm{NaOCl}$ groups (negative control vs $0.5 \% \mathrm{NaOCl}, \mathrm{p}=0.182$; negative control vs $1 \% \mathrm{NaOCl}, p=0.511$; negative control vs. $5 \% \mathrm{NaOCl}$, $\mathrm{p}=0.189$ ). The $0.5 \% \mathrm{NaOCl}$ and $5 \% \mathrm{NaOCl}$ groups had significantly lower amounts of inflammation in soft tissues compared to the positive control group (positive control vs $0.5 \% \mathrm{NaOCl}, p=0.045$; positive control vs $5 \% \mathrm{NaOCl}, \mathrm{p}=0.031$ ) (Table 3 ).

With these findings, it is possible to suggest that irrigation of osteomyelitis with $\mathrm{NaOCl}$ reduces inflammation in bone marrows and soft tissues in osteomyelitis disease.

\section{Soft Tissue Edema and Necrosis Rates were Comparable in Each Group}

Edema in soft tissues was assessed with the increase in intercellular space and neutrophil infiltration. No difference was observed between the groups. When groups were assessed in terms of soft tissue edema, no statistical difference was observed $(p=0.21)$ (Table 2).

In all groups, necrosis was observed in bone marrows and lamellar bones along with soft tissues (Figure 3). Although, a significant difference was found between the groups with respect to necrosis in bone marrows (Table 2$)(p=0.02)$, pairwise comparisons could not detect any pairwise significant difference at the 0.05 significance level $(p>0.05)$ (Table 3$)$. Thus, it can be concluded that the groups did not differ in terms of necrosis in bone marrows ( $p>0.05)$ (Table 3$)$. There was no difference observed between the groups in terms of necrosis in soft tissues also (Table 2) $(p=0.48)$. These findings show irrigation of osteomyelitis with $\mathrm{NaOCl}$ did not increase necrosis in bone marrows and soft tissues.

\section{In Vitro Results of Antibacterial Activity of $\mathrm{NaOCl}$ Against Standard Pathogenic Bacterias}

Briefly the in vitro results were given at Figure 4. The 1/64 (0.078\% $\mathrm{NaOCl})$ dilution of $\mathrm{NaOCl}$ was effective against all bacteria other than Escherichia coli. The dilution of $\mathrm{NaOCl}$ at 1/128 $(0.039 \%$ $\mathrm{NaOCl}$ ) was effective against Escherichia coli.

\section{DISCUSSION}

Previously, many experimental osteomyelitis models have been described and any foreign material is used to perform osteomyelitis models in rats $(7,22,23)$. Acute osteomyelitis in humans is generally observed with the hematogenous route without presence of foreign objects. With the aim of simulating the completely acute osteomyelitis scene, we did not use foreign objects in the acute osteomyelitis induction model unlike the osteomyeltis models which were performed by using foreign materials as bone wax, sclerosing agents, $\mathrm{K}$ wires etc. $(7,22,23)$. The standard MSSA ATCC 25923 isolate was used as it is the most common pathogen associated with implants and is successful in inducing infections $(24,25)$. The dose used for bacterial inoculation was above the minimal required dose (107 CFU) recommended by Worlock et al. (26). During preliminary studies, before beginning the experiment, the drilling and bacterial inoculation procedure were applied with an incision above the TT. However, in this preliminary study, the inoculated bacterial suspension drained out of the bone medulla through the hole which we drilled for needle entry, before we could close the hole by bone wax. We predicted the reason for this drainage was the pressure of intramedullar hemorrhage formed in the tibias. Therefore, we chose the percutaneous method as a research technique, and drilled the tibias percutaneously similar to the method Rissing et al. (16). used sclerosing agents at rats but we did not use sclerosing material as Gaudin et al. (27) method that performed at rabbits, with the concerns of not using foreign material to mimic the acute osteomyelitis model more exactly. Additionally, as there was no skin incision in our percutaneous

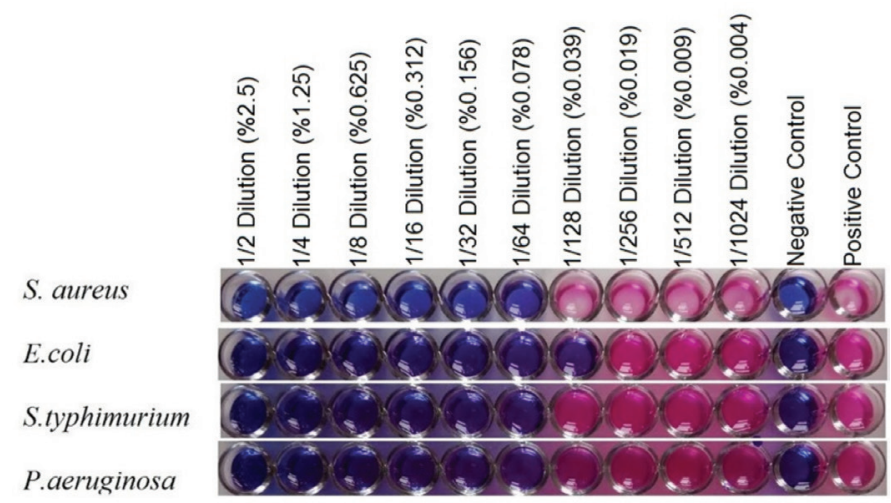

Figure 4. The in vitro results of $\mathrm{NaOCl}$ against 4 different bacterial pathogens. The used stock $\mathrm{NaOCl}$ concentration was 5\%. The concentrations of in the in vitro investigation were reduced half and half

NaOCl: Sodium hypochlorite 
technique, there was no need to use foreign materials like bone wax to close the hole formed in the bone. $\mathrm{T} 1$ contrast MRI taken 1 week after bacterial inoculation revealed contrast involvement in all tibias and soft tissues surrounding the tibias (Figure 1) (17). Histopathologically, osteomyelitis was observed in all tibia sections (Figure 2). Previously described methods have reported lower osteomyelitis development rates as $90 \%$ $(7,24)$. The probable reasons for developing acute osteomyelitis at all tibias in the present study may include 1) success of the bacterial strain (MSSA ATCC 25923) inoculated into the medulla for inducing infections (24), 2) applying bacterial inoculation above the required minimum dose $\left(10^{7} \mathrm{CFU}\right)$ for osteomyelitis development (26), and 3) keeping all of the bacterial suspension within the tibia medulla thanks to percutaneous inoculation.

As commonly known, $\mathrm{NaOCl}$ has cytotoxic effects. Therefore, whether the possible necrosis we could observe at results was due to the cytotoxic effect of $\mathrm{NaOCl}$ or the drill technique we applied was one of our major concerns. It is well known that high torque drilling or using motors perform necrosis because of heat effect (9). So, attempts were made to standardize the irrigation procedure because of the potential necrosis performing of the drilling method. Before the irrigation procedure, all tibias were kindly and slowly pitted with an 18-gauge needle tip and irrigation solutions were administered intramedullary by using a 22-gauge needle tip. The present study did not identify a significant difference in terms of necrosis of soft tissues $(p=0.48)$ (Table 2 ) and bone marrows $(p>0.05)$ (Table 3 ) between the groups (Figure 3). The lack of difference for bone marrows and soft tissues in the groups in terms of necrosis abides by the principle of "not harming the tissue" required for the ideal irrigation solution (2). Besides, at our preliminary study which we compared the saline and $\mathrm{NaOCl}$ irrigation in terms of necrosis and safety after drilling the tibia, there was not any difference between saline and $0.5 \% \mathrm{NaOCl}$ groups (unpublished data). So we think, unlike the osteomyelitis methods those use high torque motors to perform necrosis (9), current low torque drilling method made by manually did not cause additional necrosis.

The importance of acute osteomyelitis due to orthopaedic implants is increasing worldwide. The treatment of acute and chronic osteomyelitis is different from each other. The irrigation of the infected area accelerates the improvement (28). Besides if there is an implant at the body, the most important criteria was the time after the implantation surgery for the differential diagnosis of acute/chronic infection. If the time after the implantation was more than one year, the case was accepted as chronic infection. But currently the most important criteria are the time to start the complaints up to 3 weeks (29). To apply surgery and irrigation at the treatment of implant related acute infections, the irrigation solution gains more important (28).

Different solutions are commonly used in clinical practice, in order to irrigate the orthopedic infections during the surgery (36). Saline and castile soap solution were compared for irrigation of open fractures, the saline was found to be more effective (30). Azzam et al. (31) found $44 \%$ success with the application of antibiotic serum irrigation for patients with infected prosthesis. George et al. (5) recommended the irrigation with chlorhexidine in order to prevent infection in total joint prosthesis. Dakin's solution, contains $0.5 \% \mathrm{NaOCl}$, is used in diabetic foot and osteomyelitis treatments $(6,32,33)$. Before the widespread use of antibiotics, Dakin's solution is used for the continuous irrigationsuction treatment method for chronic osteomyelitis $(6,34)$. We investigated the $\mathrm{NaOCl}$, because the $\mathrm{NaOCl}$ has the advantage of effectiveness on all resistance bacteria, viruses, prions and fungi compared to other disinfectant (10). In the in vitro part of the current study $\mathrm{NaOCl}$ is germicidal even at lower concentrations (Figure 4). As $\mathrm{NaOCl}$ with concentrations from $0.5 \%$ to $5 \%$ are used for treatment purposes in humans (12-14,32,33), we researched this concentrations interval for irrigation of acute tibial osteomyelitis in the current study.

There are numerous in vitro studies with different irrigation solutions in the presence of infection (35-37). Van Meurs et al. (36) recommended povidone iodine as the ideal irrigation solution in an in vitro study. Usage of chlorhexidine with orthopedic implants was shown to reduce biofilm formation in vitro (37). Ernest et al. (35) reported that $\mathrm{NaOCl}$ reduced biofilm and bacterial concentration via in vitro studies. The suggested concentrations of $\mathrm{NaOCl}$ at in vivo $(6,32-33)$ and in vitro $(11,35,38,39)$ studies are different each other. The suggested concentrations of $\mathrm{NaOCl}$ is lower $(0.01 \mathrm{NaOCl})$ at in vitro (11) studies than in vivo and human $(0.5-5 \% \mathrm{NaOCl})(6,12-14,32,33)$ studies. This is most probably because of the lack of defense system of living organism, as white blood cell, macrophages, immune system, hormones etc, at in vitro conditions.

Irrigation alone is not sufficient for osteomyelitis treatment (40). However, it is an important stage in surgery. The criteria (2) for the ideal irrigation fluid are as follows: 1) It should reduce the number of pathogens mechanically by irrigating the surgical site 2) it should reduce the number of pathogens by antimicrobial effect 3) it should not cause side effects such as damaging the tissues. In our study we found: 1) Soft tissue (Table 2) and bone marrow (Table 3) necrosis were insignificant between the groups, abiding by the lack of harm condition for the ideal irrigation 
fluid, 2) the reduction in bacterial density with the use of $\mathrm{NaOCl}$ abides by the condition of reducing the density of bacteria mechanically and through antimicrobial effect, and 3) the reduction of inflammation in soft tissues and bones with the use of $\mathrm{NaOCl}$ may be interpreted as $\mathrm{NaOCl}$ to be a marker that regresses the disease. This study revealed the histological results of $\mathrm{NaOCl}$ irrigation in acute osteomyelitis of the long bones.

In terms of treatment efficacy, the most important aspect of this study was the decrease in bacterial density. When compared with the negative control group, all three $\mathrm{NaOCl}$ groups were observed to have significantly reduced bacterial density $(p<0.001, p=0.039$ and $p<0.001$, respectively) (Table 3 ). When $\mathrm{NaOCl}$ groups were compared with the positive control group in terms of bacterial density, only the $0.5 \% \mathrm{NaOCl}$ group had a significant reduction in bacterial density $(p=0.019)$. But when the $1 \% \mathrm{NaOCl}$ and $5 \%$ $\mathrm{NaOCl}$ groups were compared with the positive control group in terms of bacterial density, no statistical difference was observed $(p=0.192, p=0.349$ and $p=0.186$, respectively) (Table 3). Higher concentrations of $\mathrm{NaOCl}$ can be predicted to be more bactericidal. But this situation is in accordance with the literature; it is known that lower concentration of alcohol is more bactericidal than that of higher concentrations $(41,42)$. A recently study made by our study group revealed that $\mathrm{H}_{2} \mathrm{~S}$, a toxic hormone at higher concentrations, can be therapeutic at physiological low doses (43). Besides, Wong and Cheung (44) applied 0.5\% and 3\% concentrations of $\mathrm{NaOCl}$ for irrigation and searched for bacterial density in an ex vitro study made with extracted human teeth. The $0.5 \% \mathrm{NaOCl}$ and $3 \% \mathrm{NaOCl}$ groups were found to be statistically insignificant in reducing bacterial density. In our study, statistically compared with both the negative and positive control groups, the only treatment group that significantly reduced bacterial density was the $0.5 \% \mathrm{NaOCl}$ group (Table 3). This feature of $0.5 \%$ $\mathrm{NaOCl}$ abides by the principle (2) of antimicrobial effect desired in the ideal irrigation solution.

Osteomyelitis does not only affect bone tissues but also the surrounding soft tissues (45). Hence, when bones recover from the disease, soft tissues start to recover as well. We detected inflammation to be reduced in bone marrows $(p=0.002)$ and soft tissues $(p=0.02)$ in the first 24 hours after irrigation of osteomyelitis with $\mathrm{NaOCl}$ (Figure 3) (Table 2). This situation may be interpreted as $\mathrm{NaOCl}$ irrigation of bone with acute osteomyelitis may has therapeutic effects on bones and surrounding soft tissues.

Based on the results of the first 24 hours, there was no statistical difference identified between the groups in terms of soft tissue edema ( $p=0.21$ ) (Figure 3) (Table 2). The edema formed by $\mathrm{NaOCl}$ in soft tissues disappears within 24-48 hours in clinic (12). This finding may be assessed as irrigation with $\mathrm{NaOCl}$ does not cause additional edema in soft tissues.

\section{CONCLUSION}

In conclusion, 1) experimental acute osteomyelitis developed in all tibias by using the percutaneous bacterial inoculation 2) the findings indicate that $0.5 \% \mathrm{NaOCl}$ is beneficial for irrigation of acute osteomyelitis and there is a need for further studies on the topic.

\section{Ethics}

Ethics Committee Approval: The study was conducted upon the permission of local ethics committee for animal experiments (HADYEK, 15.12.2016, 2016/16) Republic of Turkey Ordu University Animal Experiments Local Ethics Committee.

Informed Consent: Animal experiments.

Peer-review: Externally and internally peer-reviewed.

\section{Authorship Contributions}

Concept: K.A., C.Z.E., Design: K.A., C.Z.E., Data Collection or Processing: A.D., I.C.., F.Y.A., S.D., Analysis or Interpretation: C.Z.E., E.A., Literature Search: A.D., F.Y.A., Writing: K.A., S.T., C.Z.E.

Conflict of Interest: No conflict of interest was declared by the authors.

Financial Disclosure: This study has been supported by Giresun University Scientific Research Center (SAĞ-BAP-A-160317-74).

\section{REFERENCES}

1. Kapukaya A, Subașı M, Kaya H, Kesemenli C, Sarı I, Kandiya E. Akut osteomyelit tedavisinde granulocyte rnacrophage-colony stirnulating factor (GM-CSF)'ün etkisi. Acta Ortop Traumatol Turc 1998;32:325-8.

2. Tiemann AH, Hofmann GO. Wound irrigation within the surgical treatment of osteomyelitis. GMS Interdiscip Plast Reconstr Surg DGPW 2012:1.

3. Campbell ST, Goodnough LH, Bennett CG, Giori NJ. Antiseptics commonly used in total joint arthroplasty interact and may form toxic products. J Arthroplasty 2018;33:844-6.

4. Conroy BP, Anglen JO, Simpson WA, Christensen G, Phaup G, Yeager R, et al. Comparison of castile soap, benzalkonium chloride, and bacitracin as irrigation solutions for complex contaminated orthopaedic wounds. J Orthop Trauma 1999;13:332-7.

5. George J, Klika AK, Higuera CA. Use of chlorhexidine preparations in total joint arthroplasty. J Bone Jt Infect 2017;2:15-22.

6. Taylor AR, Maudsley RH. Instillation-suction technique in chronic osteomyelitis. J Bone Joint Surg Br 1970;52:88-92.

7. Patel M, Rojavin Y, Jamali AA, Wasielewski SJ, Salgado CJ. Animal models for the study of osteomyelitis. Semin Plast Surg 2009;23:148-54. 
8. McPherson JC 3rd, Runner RR, Shapiro B, Walsh DS, Stephens-DeValle J, Buxton TB. An acute osteomyelitis model in traumatized rat tibiae involving sand as a foreign body, thermal injury, and bimicrobial contamination. Comp Med 2008;58:369-74.

9. Korkusuz F, Uchida A, Shinto Y, Araki N, Inoue K, Ono K. Experimental implant-related osteomyelitis treated by antibiotic-calcium hydroxyapatite ceramic composites. J Bone Joint Surg Br 1993;75:111-4.

10. Center for Disease Control and Prevention (2016). Disinfection ByProducts. Available from: https://www.cdc.gov/safewater/chlorinationbyproducts.html Accessed 20 February 2019.

11. Heling I, Rotstein I, Dinur T, Szwec-Levine Y, Steinberg D. Bactericidal and cytotoxic effects of sodium hypochlorite and sodium dichloroisocyanurate solutions in vitro. J Endod 2001;27:278-80.

12. Pashley EL, Birdsong NL, Bowman K, Pashley DH. Cytotoxic effects of $\mathrm{NaOCl}$ on vital tissue. J Endod 1985;11:525-8.

13. Zan R, Kutlu G, Hubbezoglu I, Sumer Z, Tunc T, Mutlu Z. Bactericidal effects of various irrigation solutions against Staphylococcus Aureus in human root canal. J Istanb Univ Fac Dent 2015;49:19-26.

14. Mathew ST. Risks and management of sodium hypochlorite in endodontics. Journal of Oral Hygiene Health 2015:1-5.

15. www.nap.edu/catalog/5140.html Accessed 20 February 2019

16. Rissing JP, Buxton TB, Weinstein RS, Shockley RK. Model of experimental chronic osteomyelitis in rats. Infect Immun 1985;47:581-6.

17. Lee YJ, Sadigh S, Mankad K, Kapse N, Rajeswaran G. The imaging of osteomyelitis. Quant Imaging Med Surg 2016;6:184-98.

18. Tiemann A, Hofmann GO, Krukemeyer MG, Krenn V, Langwald S. Histopathological Osteomyelitis Evaluation Score (HOES)-an innovative approach to histopathological diagnostics and scoring of osteomyelitis. GMS Interdiscip Plast Reconstr Surg DGPW 2014:3.

19. Koo TK, Li MY. A guideline of selecting and reporting intraclass correlation coefficients for reliability research. J Chiropr Med 2016;15:155-63.

20. Kruskal WH, Wallis WA. Use of ranks in one-criterion variance analysis. J Am Stat Assoc 1952;47:583-621.

21. Dunn 0J. Multiple comparisons using rank sums. Technometrics 1964;6:241-52.

22. Reizner W, Hunter JG, O'Malley NT, Southgate RD, Schwarz EM, Kates SL. A systematic review of animal models for Staphylococcus aureus osteomyelitis. Eur Cell Mater 2014;27:196-212.

23. Lucke M, Schmidmaier G, Sadoni S, Wildemann B, Schiller R, Stemberger A, et al. A new model of implant-related osteomyelitis in rats. Journal of Biomedical Materials Research 2003;67:593-602.

24. Harrasser N, Gorkotte J, Obermeier A, Feihl S, Straub M, Slotta-Huspenina J, et al. A new model of implant-related osteomyelitis in the metaphysis of rat tibiae. BMC Musculoskeletal Disorders 2016;17:152.

25. Haenle M, Zietz C, Lindner T, Arndt K, Vetter A, Mittelmeier W, et al. A model of implant-associated infection in the tibial metaphysis of rats. ScientificWorldJournal 2013;2013:481975.

26. Worlock P, Slack R, Harvey L, Mawhinney R. An experimental model of post-traumatic osteomyelitis in rabbits. Br J Exp Pathol 1988;69:235-44.

27. Gaudin A, Amador Del Valle G, Hamel A, Le Mabecque V, Miegeville AF, Potel G, et al. A new experimental model of acute osteomyelitis due to methicillin-resistant Staphylococcus aureus in rabbit. Lett Appl Microbiol 2011;52:253-7.
28. Kuiper JW, Vos SJ, Saouti R, Vergroesen DA, Graat HC, DebetsOssenkopp YJ, et al. Prosthetic joint-associated infections treated with DAIR (debridement, antibiotics, irrigation, and retention) Analysis of risk factors and local antibiotic carriers in 91 patients. Acta Orthop 2013;84:380-6.

29. Li C, Renz N, Trampuz A. Management of periprosthetic joint infection. Hip Pelvis 2018;30:138-46.

30. FLOW Investigators, Bhandari M, Jeray KJ, Petrisor BA, Devereaux PJ, Heels-Ansdell D. A trial of wound irrigation in the initial management of open fracture wounds. N Eng J Med 2015;373:2629-41.

31. Azzam KA, Seeley M, Ghanem E, Austin MS, Purtill JJ, Parvizi J. Irrigation and debridement in the management of prosthetic joint infection: traditional indications revisited. J Arthroplasty 2010;25:1022-7.

32. Duarte B, Cabete J, Formiga A, Neves J. Dakin's solution: is there a place for it in the 21st century? Int Wound J 2017;14:918-20.

33. Cornwell P, Arnold-Long M, Barss SB, Varnado MF. The use of Dakin's solution in chronic wounds: a clinical perspective case series. J Wound Ostomy Continence Nurs 2010;37:94-104.

34. Michelinakis E. Treatment of chronic osteomyelitis with the continuous irrigation-suction method. Acta Orthop Scand 1972;43:25-31.

35. Ernest EP, Machi AS, Karolcik BA, LaSala PR, Dietz MJ. Topical adjuvants incompletely remove adherent Staphylococcus aureus from implant materials. J Orthop Res 2018;36:1599-604.

36. Van Meurs SJ, Gawlitta D, Heemstra KA, Poolman RW, Vogely HC, Kruyt MC. Selection of an optimal antiseptic solution for intraoperative irrigation: an in vitro study. J Bone Joint Surg Am 2014;96:285-91.

37. Schwechter EM, Folk D, Varshney AK, Fries BC, Kim SJ, Hirsh DM. Optimal irrigation and debridement of infected joint implants: an in vitro methicillin-resistant Staphylococcus aureus biofilm model. J Arthroplasty 2011;26:109-13.

38. Hidalgo E, Bartolome R, Dominguez C. Cytotoxicity mechanisms of sodium hypochlorite in cultured human dermal fibroblasts and its bactericidal effectiveness. Chem Biol Interact 2002;139:265-82.

39. Sawada K, Caballe-Serrano J, Bosshardt DD, Schaller B, Miron RJ, Buser $D$, et al. Antiseptic solutions modulate the paracrine-like activity of bone chips: differential impact of chlorhexidine and sodium hypochlorite. J Clin Periodontol 2015;42:883-91.

40. Azzam K, Parvizi J, Jungkind D, Hanssen A, Fehring T, Springer B, et al. Microbiological, clinical, and surgical features of fungal prosthetic joint infections: a multi-institutional experience. J Bone Joint Surg Am 2009;91(Suppl 6):142-9.

41. Center for Disease Control and Prevention (2008) Chemical Disinfectants. Available from: https://www.cdc.gov/ infectioncontrol/ guidelines/ disinfection/ disinfection-methods/ chemical.html Accessed 20 February 2019.

42. McDonnell G, Russell AD. Antiseptics and disinfectants: activity, action, and resistance. Clin Microbiol Rev 1999;12:147-79.

43. Aytekin K, Erhan SŞ, Erişgin Z, Esenyel CZ, Takır S. Intra-articular injection of hydrogen sulfide decreased the progression of gonarthrosis. Can J Physiol Pharmacol 2018;97:47-54.

44. Wong DT, Cheung GS. Extension of bactericidal effect of sodium hypochlorite into dentinal tubules. J Endod 2014;40:825-9.

45. Öztuna V. Osteomiyelit Patofizyolojisi ve Tedavi Prensipleri. TOTBID Dergisi 2005;4:63-71. 